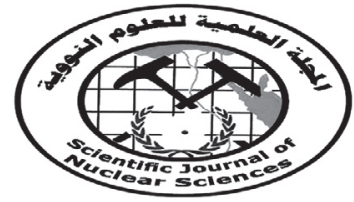

Nuclear Materials Authority

P.O.Box 530 Maadi, Cairo, Egypt
ISSN 2314-5609

Nuclear Sciences Scientific Journal vol. $1, \mathrm{p} 99-118$

2012

\title{
RADIOACTIVE ACCESSORY MINERALS FROM STREAM SEDIMENTS AT WADI MAYET EL ABD, NORTHERN GATTAR AREA NORTH EASTERN DESERT, EGYPT.
}

\author{
SALAH S. ELBALAKSSY, MOHAMED A. EL ZALAKY \\ and AHMED A. ABU STEET \\ Nuclear Materials Authority, P.O. Box 530, El Maadi, Cairo, Egypt
}

\begin{abstract}
Wadi Mayet El-Abd is located in the northern part of G. Gattar, north Eastern Desert of Egypt. Significant remarks have been recorded on the heterogeneous distributions of heavy minerals content along the stream course, where they are most common in both deeper sediments and downstream sites. Moreover, these sediments appear to be slightly favorable delivery pools for thorium but not for uranium which is probably due to either the marked enrichment in the thorium-bearing minerals or the selective leaching for uranium during the supergene processes. The greater eU/U and eTh/U ratios, besides the negative values of the calculated authigenic uranium and further the markedly reverse relationships between uranium and thorium as well as uranium and $\mathrm{Th} / \mathrm{U}$ ratio reveal the disequilibrium state of uranium and confirm $\mathrm{U}$ leaching. The available data propose that, the study sediments are potential sink for radioactive accessory minerals as well as rare metal minerals that may control the geochemical enrichment of trace elements as; $\mathrm{U}, \mathrm{Th}, \mathrm{Zr}, \mathrm{Y}, \mathrm{Nb}, \mathrm{REE}, \mathrm{Ba}, \mathrm{Zn}$ and V. The present work adopts the ESEM/EDXBSE as an appropriate tool for the recognition of the accessory minerals. The minerals; betafite, ishikawaite, xenotime, fluorite and zircon have been identified as the most abundant uraniferous accessory minerals; whereas monazite dominates as thorium-bearing mineral. Moreover, thorite and uranothorite have occasionally been recognized. A particular attention has been given to the contents of the rare metals in general and radionuclides in paticular in the accessory minerals, despite of their frequency in the whole stream sediments. In conclusion, the study sediments are conceivably genetically related to common sources. Actually it reflects the mineral constituent of the different rocks composing the drained area. Hence it may represent an erosional remnant either of the bordering granites and Hammamat molasses terrenes of Wadi Mayet El- Abd or drained from the further reaches which represent by the nearby weathered sediments of Wadi Belih at downstream sites.
\end{abstract}

\section{INTRODUCTION}

Gattar area is situated in the north Eastern Desert of Egypt including Wadi Mayet El-Abd; covering an area of about $450 \mathrm{~km}^{2}$ between Lat. $27^{\circ} 00^{\prime}$ and $27^{\circ} 06^{\prime} \mathrm{N}$ and Long. $33^{\circ} 14^{\prime}$ and $33^{\circ}$ 23' E (Fig.1). Wadi Mayet El-Abd is located in the northern part of G. Gattar and south G. Um Tawat (Sheet, NG36 O1b, Gabal Abu Dokhan, 1:50 000). It is considered as the main tributary of Wadi Belih with a length of about 7.0 $\mathrm{km}$. The studied wadi course appears to be as an open drainage; narrow upstream and very 
wide downstream. In addition, the attitudes of contour lines indicate that the main slope of W. Mayet El Abd is looking in north direction, toward Wadi Balih. Mayet El Abd area includes different rock types represented from older to younger by Hammamat sedimentary rocks (molasses), acidic dykes, younger granites, basic dykes and Quaternary sediments (Fig. 1). The younger granites at the northern part of G. Gattar exposed at Wadi Mayet El Abd are represented by syenogranites (Salman et al., 1994). These granites are invaded by one set of three basic dykes striking $\mathrm{N} 30^{\circ} \mathrm{E}$ which were displaced by a major sinestral strike-slip fault striking N-S. The area has a rugged topography, where the elevations rapidly change (Fig. 2a).

As a result, the stream sediments of $\mathrm{W}$. Mayet El Abd have a rather heterogeneous nature. Their detritus are unconsolidated, loose and have different forms and sizes. They are angular, sub-rounded to well rounded (Fig.2b), reflecting the changes in the energy of the stream flow. Thus, it is mostly described as alluvial deposits with some of eluvial as well as residual deposits. Hassaan (1999) reported that the stream sediments of W. Mayet El Abd consist mostly of gravel, sand and mud. Sand comprises $57 \%$, the very coarse and very poorly sorted sand are dominant. Generally, various factors may control the depositional regime of these sediments as the fluctuation of hydraulics of the stream flow. In agreement with Dissanayake et al. (2000), the intensity and distance of transportation from the source and the topographical suitability of the sites for deposition are among the main factors.

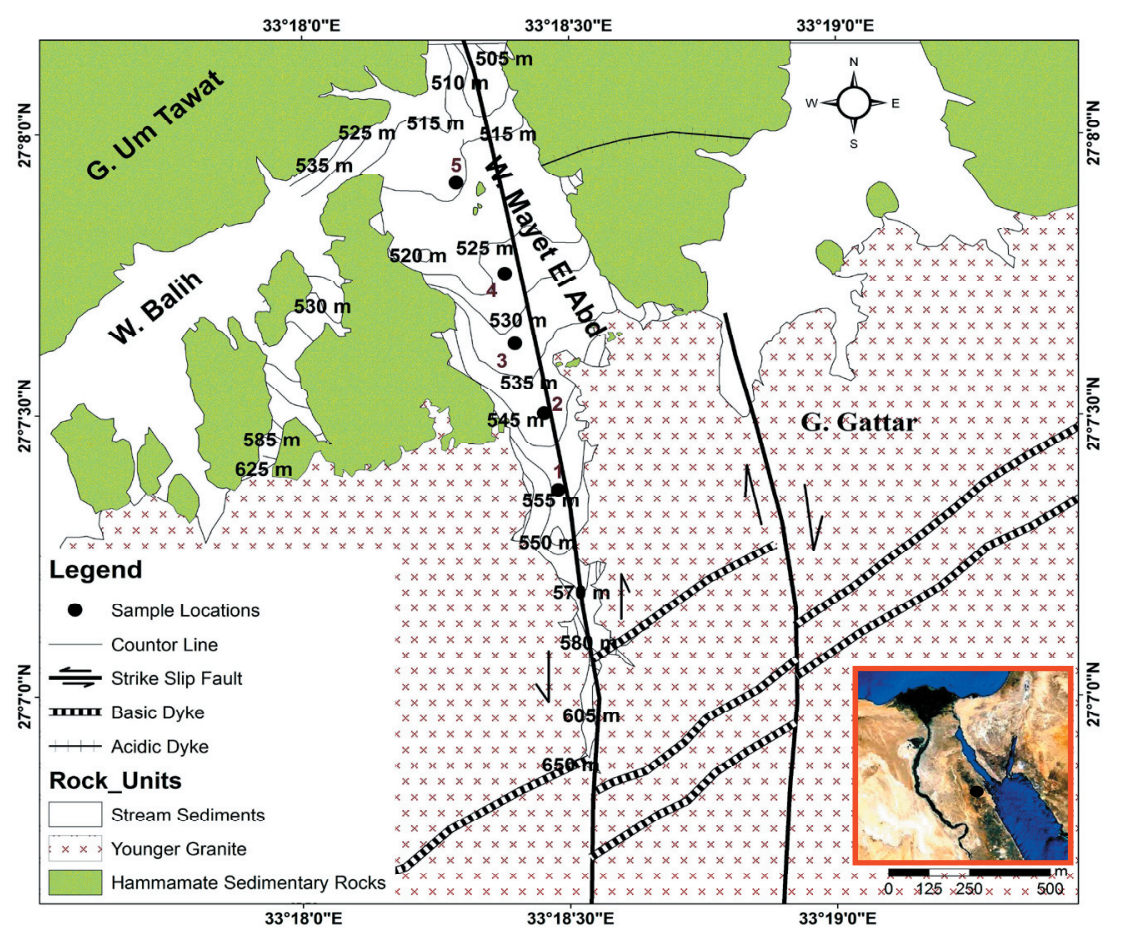

Fig.1. Geological map of W. Mayet El Abd area extracted from high resolution satellite image 


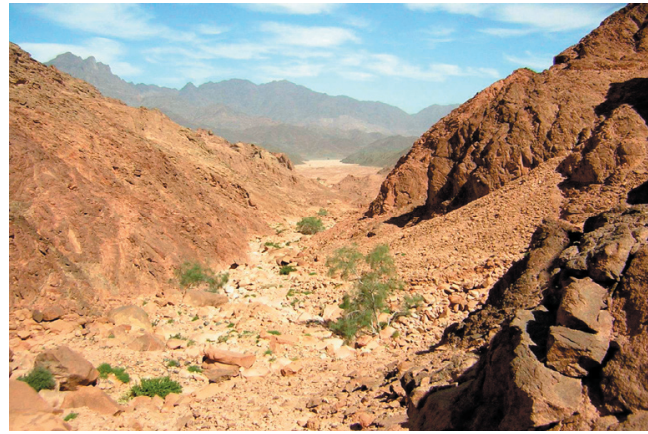

Fig. 2 a. Field photograph of the studied area showing: general view of W. Mayet El-Abd area, looking north

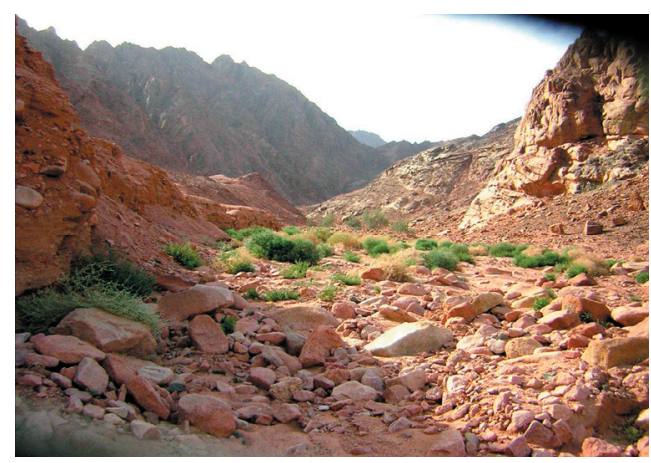

Fig. 2 b. Field photograph showing the characteristic nature of the sediments along W. Mayet El-Abd

However, as far as the authors are aware, most previous studies spotlighted only on the granitoids and the Hammamat sedimentary rocks of the Gattar pluton (c.f., Attawiya, 1990; Mahdy et al., 1990; Sayyah and Attawya, 1990; Shalaby, 1990; Salman et al., 1991; El Rakaiby and Shalaby, 1992; Roz, 1994; Salman et al., 1994; Abu Zaid, 1995; Shalaby, 1995;Nossier 1996; El Bouhy, 1997; El Kammar et al., 2001; Bishta, 2004; Esmail, 2005; Nossair, 2005; El Zalaky, 2007; Shalaby et al., 2010 and El Balakssy, 2012). The studies on the stream sediments are certainly insufficient and immature. Therefore, the present paper is an attempt to contribute to the available database on the radioactive and rare metalbearing minerals in the stream sediments of W. Mayet El Abd. Especial attention will be paid to the naturally occurring radionuclides in these sediments. Recommendations on the importance of the optimistic potential resource for radionuclides and other rare metals in W. Mayet El-Abd stream sediments will be suggested. The present study may encourage the Nuclear Materials Authority (NMA) of Egypt to conduct an exploration program in the near future.

\section{SAMPLING AND METHODOLOGY}

In order to achieve the main goal of this study, ten representative samples at interval of about half kilometer apart were collected along the stream course. The weight varies from 25 to $40 \mathrm{~kg}$ for each. The samples were actually collected at two depth levels $(50 \mathrm{~cm}$ $\& 100 \mathrm{~cm}$ ) from the upstream as well as the downstream to explore the influence of the hinterland. Several experimental techniques have been done including; the silty size fractions were subjected to the chemical analysis that was done by conventional techniques for the major oxides and X-ray fluorescence using Philips $\mathrm{X}$-Unique II spectrometer (PW1510) for the trace elements. Gammaray spectrometry multichannel analyzer to measure the four radionuclides; eU, eTh, Ra and $\mathrm{K}$. In addition, Arsenazo-III was used as reagent for the spectrophotometric analysis of uranium and thorium while Arsenazo-I for the total REE.

Heavy minerals separation of the sand size class $<0.5 \mathrm{~mm}$ has been accomplished by bromoform followed by magnetic fractionation using the Frantz Isodynamic Separator model (L-1). Further purification was thoroughly achieved by picking under stereo-microscope. The separated mineral grains were examined under environmental scanning electron microscope (ESEM) model Philips XL 30, attached with dispersive X-ray spectra (EDX) microanalyzer at an operating voltage of $25 \mathrm{kV}, 1-2 \mathrm{~mm}$ beam diameter, 60-120 second counting time and high-resolution backscattered electron images (BSE). 
The frequencies of the identified radioactive accessory minerals at different depth levels have been estimated by counting under stereo binocular microscope. All analyses are currently being done in the Nuclear Materials Authority (NMA) Labs. Cairo, Egypt.

\section{RESULTS AND DISCUSSIONS}

\section{Geochemistry}

The geochemical analyses of the studied stream sediments are listed in Table (1) for major oxides and Table (2) for trace elements. The obtained data propose that, the study sediments are markedly enriched in $\mathrm{Al}_{2} \mathrm{O}_{3}$ and $\mathrm{CaO}$ besides, the fairly low saturation of $\mathrm{Fe}_{2} \mathrm{O}_{3}$. In contrast, the $\mathrm{SiO}_{2}$ content is slightly depleted. On the other hand, the distribution of trace elements with respect to depth levels does not reflect an explicit geochemical trend, however, their concentrations are relatively enriched in upstream sediments, particularly in $\mathrm{Zr}$, $\mathrm{Ba}, \mathrm{Nb}$ and $\mathrm{Y}$ (Figs.3a\&b). In contrast, the total REE are relatively enriched in deeper levels of the concerned sediments than surface one. Thus, consistent and common source(s) can be initially assumed; granitic rocks of the source area.

Table 1: Major oxides (wt \%) analysis of stream sediments in W. Mayet El-Abd area

\begin{tabular}{l|rrrrr|rrrrr}
\hline Major & \multicolumn{3}{|c|}{ Surface samples (50cm) } & \multicolumn{5}{c}{ Subsurface samples $(100 \mathrm{~cm})$} \\
\cline { 2 - 11 } Oxides & $1 \mathrm{a}$ & $2 \mathrm{a}$ & $3 \mathrm{a}$ & $4 \mathrm{a}$ & $5 \mathrm{a}$ & $1 \mathrm{~b}$ & $2 \mathrm{~b}$ & $3 \mathrm{~b}$ & $4 \mathrm{~b}$ & $5 \mathrm{~b}$ \\
\hline $\mathrm{SiO}_{2}$ & 40.66 & 40.15 & 42.69 & 39.95 & 40.38 & 42.97 & 43.33 & 46.41 & 47.1 & 42.96 \\
$\mathrm{TiO}_{2}$ & 0.3 & 1.2 & 1.4 & 1.2 & 0.9 & 0.9 & 1.2 & 0.3 & 0.4 & 1.1 \\
$\mathrm{Al}_{2} \mathrm{O}_{3}$ & 19 & 19 & 16 & 17 & 19 & 14 & 19 & 18 & 14 & 12 \\
$\mathrm{Fe}_{2} \mathrm{O}_{3}$ & 6.39 & 9.34 & 9.82 & 8.06 & 7.98 & 7.99 & 9.15 & 8.06 & 4.23 & 6.91 \\
$\mathrm{MgO}$ & 2.6 & 1.4 & 1.0 & 1.2 & 0.2 & 1.8 & 3.2 & 2.2 & 2.8 & 4.6 \\
$\mathrm{CaO}$ & 14.8 & 10.6 & 12.3 & 14 & 15.4 & 15.7 & 10.2 & 10.6 & 13.4 & 10.6 \\
$\mathrm{Na}$ & 1.38 & 1.38 & 1.51 & 1.42 & 1.47 & 1.3 & 1.47 & 1.9 & 1.81 & 2.01 \\
$\mathrm{~K}_{2} \mathrm{O}$ & 1.25 & 1.29 & 1.32 & 1.25 & 1.37 & 1.2 & 1.29 & 1.42 & 1.42 & 1.37 \\
$\mathrm{P}_{2} \mathrm{O}_{5}$ & 0.12 & 0.15 & 0.08 & 0.18 & 0.21 & 0.15 & 0.07 & 0.11 & 0.32 & 0.16 \\
L.O.I & 12.5 & 13.54 & 12.96 & 13.76 & 12.21 & 13.4 & 11.07 & 10.82 & 13.56 & 13.62 \\
\hline Total & 99.00 & 98.05 & 99.08 & 98.02 & 99.12 & 99.4 & 99.98 & 99.82 & 99.04 & 99.33 \\
\hline
\end{tabular}

Table 2: Trace and total REE (ppm) analyses of stream sediments in W. Mayet El-Abd

\begin{tabular}{l|rrrrr|r|rrrrr|r}
\hline Trace & \multicolumn{6}{|c|}{ Surface samples } & \multicolumn{5}{|c}{ Subsurface samples } & \\
\cline { 2 - 12 } elements & $1 \mathrm{a}$ & $2 \mathrm{a}$ & $3 \mathrm{a}$ & $4 \mathrm{a}$ & $5 \mathrm{a}$ & Av. & $1 \mathrm{~b}$ & $2 \mathrm{~b}$ & $3 \mathrm{~b}$ & $4 \mathrm{~b}$ & $5 \mathrm{~b}$ & Av. \\
\hline $\mathrm{Cr}$ & 35 & 31 & 35 & 33 & 34 & 34 & 36 & 31 & 36 & 33 & 34 & 34 \\
$\mathrm{Ni}$ & 21 & 20 & 22 & 19 & 20 & 20 & 21 & 18 & 22 & 27 & 22 & 22 \\
$\mathrm{Cu}$ & 11 & 10 & 13 & 12 & 13 & 12 & 11 & 10 & 12 & 12 & 16 & 12 \\
$\mathrm{Zn}$ & 63 & 60 & 78 & 59 & 64 & 65 & 59 & 65 & 85 & 86 & 75 & 74 \\
$\mathrm{Zr}$ & 814 & 789 & 678 & 594 & 612 & 697 & 1005 & 825 & 785 & 435 & 694 & 749 \\
$\mathrm{Rb}$ & 62 & 53 & 63 & 56 & 61 & 59 & 58 & 63 & 76 & 73 & 70 & 68 \\
$\mathrm{Y}$ & 497 & 481 & 414 & 358 & 368 & 424 & 621 & 503 & 483 & 244 & 429 & 456 \\
$\mathrm{Ba}$ & 1141 & 1036 & 1075 & 1013 & 995 & 1052 & 1175 & 1038 & 1075 & 1060 & 1006 & 1072 \\
$\mathrm{~Pb}$ & $\mathrm{Ud}$ & $\mathrm{ud}$ & $\mathrm{Ud}$ & $\mathrm{ud}$ & $\mathrm{ud}$ & 0 & $\mathrm{ud}$ & $\mathrm{ud}$ & $\mathrm{ud}$ & $\mathrm{ud}$ & $\mathrm{ud}$ & 0 \\
$\mathrm{Sr}$ & 29 & 29 & 25 & 22 & 22 & 25 & 36 & 30 & 28 & 15 & 25 & 27 \\
$\mathrm{Ga}$ & 23 & 25 & 23 & 25 & 25 & 24 & 23 & 22 & 24 & 24 & 23 & 23 \\
$\mathrm{~V}$ & 43 & 38 & 41 & 37 & 36 & 39 & 41 & 36 & 41 & 43 & 39 & 40 \\
$\mathrm{Nb}$ & 42 & 45 & 47 & 50 & 49 & 45 & 39 & 47 & 45 & 48 & 44 & 45 \\
$\mathrm{U}$ & 10 & 15 & 11 & 14 & 16 & 13 & 18 & 17 & 19 & 16 & 22 & 18 \\
$\mathrm{Th}$ & 70 & 72 & 81 & 88 & 57 & 74 & 66 & 71 & 52 & 49 & 43 & 54 \\
\hline $\mathrm{REEs}$ & 93 & 153 & 65 & 145 & 120 & 115 & 181 & 223 & 170 & 183 & 186 & 189 \\
\hline
\end{tabular}




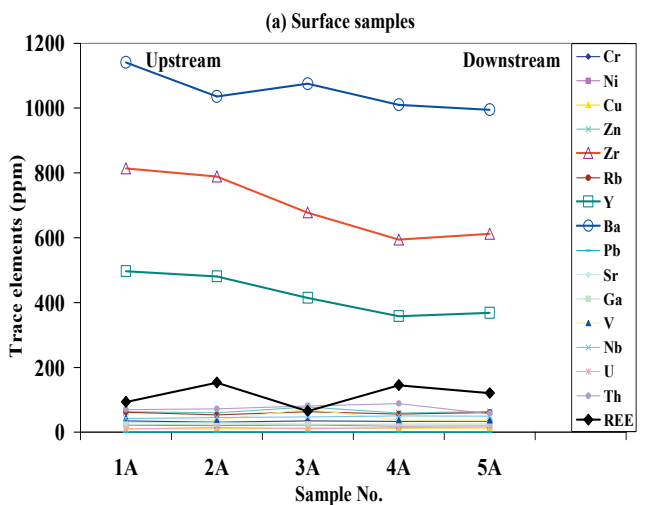

Fig.3a: Distribution of trace elements in the surface sediment samples

The very high Ba content (995-1175 ppm), relative to other stream sediments of Egypt (El Balakssy, 2006 and Abu Bakr et al., 2007) can be considered as a prominent geochemical signature of the study sediments. Thus, the abnormal enrichment of barium in the studied stream sediments point of view and in the hematized granitic rocks, $2195 \mathrm{ppm}$ in average as well as in Hammamat sediments; $1135 \mathrm{ppm}$ in average of W. Mayet El Abd area (El Balakssy, 2012) still a matter of contrivers and need more detail investigation. The enrichment of barium within the study area suppose that the area most probably affected by high intensive hydrothermal solutions (El Zalaky, 2007 and El Balakssy, 2012). Besides, barium is normally considered to be captured by potassium-bearing phases during the differentiated sequence of the magma (Rankama and Sahama, 1950). Dissanayake et al., (2000) stated that the geochemical enrichment of some trace elements in stream sediments is related to highly fractionated source belonging to granitic melts during the late stage magmatic events. Moreover, the highly differentiated granites are conventionally enriched in rare metals carriers such as zircon and monazite. Accordingly, it suggests that the mineralized granitic rocks dominating in the hinterlands of the study area are one of the main sources that provided the materials for enrichment.

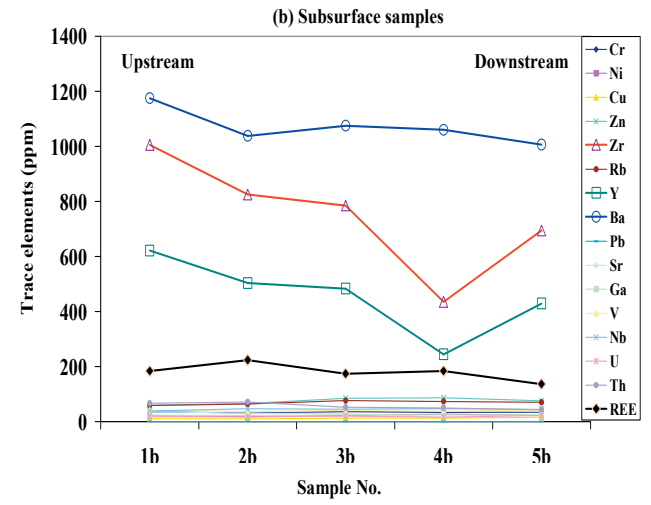

Fig.3b: Distribution of trace elements in the subsurface sediment samples

Meanwhile, $\mathrm{Nb}$ and $\mathrm{Ba}$ display weak negative relationships with the chemically analyzed $U$, whereas opposite trend with thorium has been encountered (Figs. 4a-d). This can be interpreted to the immobile nature of Th relative to U. Likely, $\mathrm{Zr}$ shows very weak positive correlation with both $\mathrm{U}$ and Th (Figs. $4 \mathrm{e}-\mathrm{f})$ probably due to the low mobility of $\mathrm{Zr}$, and implies that the studied zircon is partially significant carrier of $U$ and $T h$. In addition, the elements; $\mathrm{Zn}, \mathrm{Rb}, \mathrm{V}$ and $\mathrm{Ga}$ are slightly enriched within the studied sediments. The present data on $\mathrm{Zn}$ and $\mathrm{Rb}$ are slightly higher than the average crustal values; 40 ppm (Rose et al., 1979). Rb correlates positively with the chemically analyzed $\mathrm{U}$ but negatively with $\mathrm{Th}$ (Figs. 4g \&h). Vanadium may be genetically related to the anomalous concentration in the different rock types that encountered the studied area as the basic dykes; varies from 262 to $304 \mathrm{ppm}$, Hammamat sediments; $121 \mathrm{ppm}$ and the altered granites varies from 136 to $141 \mathrm{ppm}$ as perceived earlier by El Balakssy (2012). On the other hand, some base metals as $\mathrm{Cr}, \mathrm{Ni}$ and $\mathrm{Cu}$ are depleted in the concerned sediments; presumably due to the absence of the basic rocks in the studied area. In addition, a remarkable depletion in $\mathrm{Pb}$ was noticed; it is below detection limit, their deficiency may be attributed to the lack of lead-bearing minerals. The sediments was also found to con- 


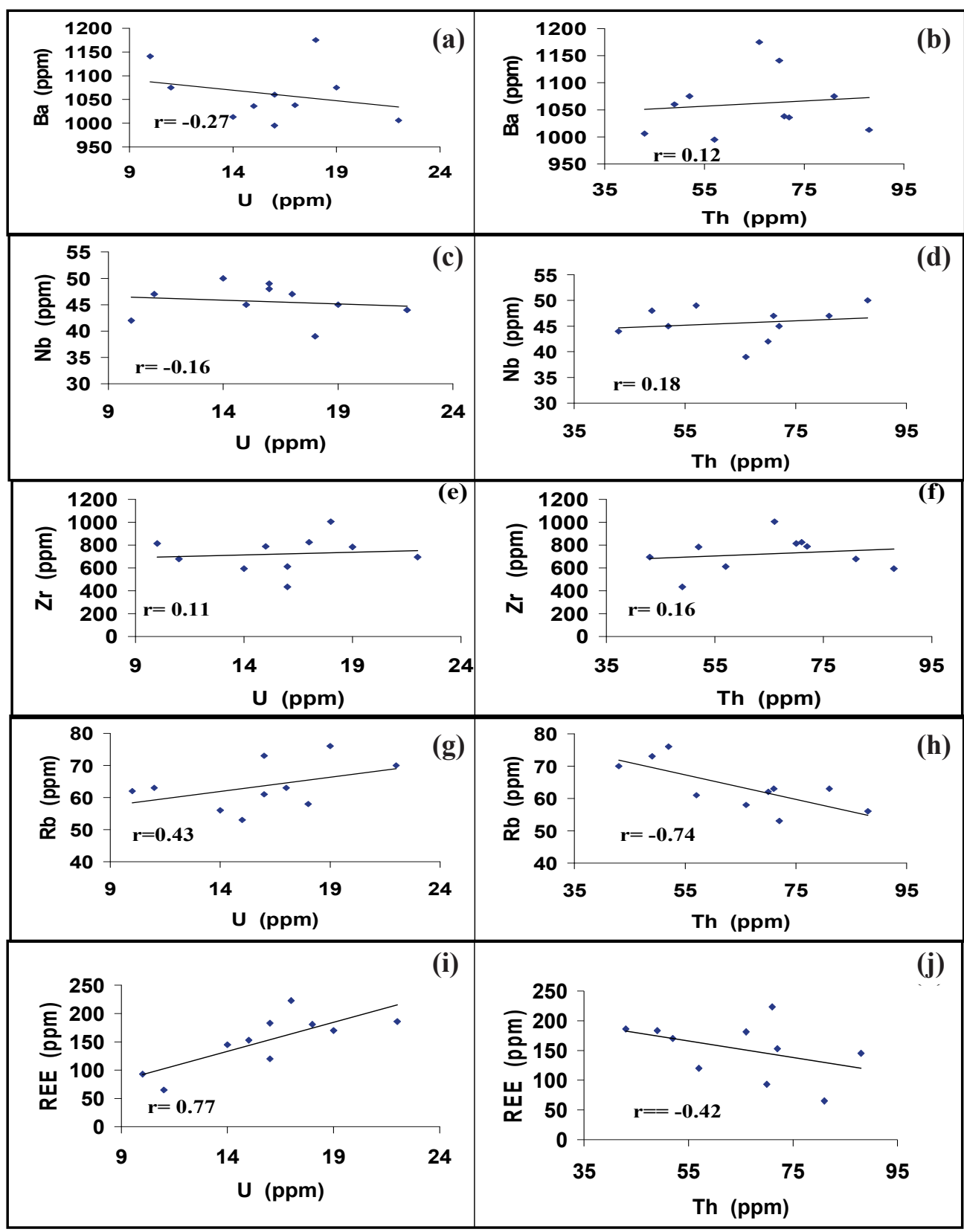

Fig.4 Correlation diagrams of uranium (ppm) and thorium (ppm) versus some of trace elements in the studied stream sediments (the trends represents surface values plus subsurface one together) 
tain relative low Sr content; varies from 15 to $36 \mathrm{ppm}$, it lie within the typical range of the average crustal values; 20 ppm (Rose et al., 1979). Since strontium is considered as a mobile element in both oxidizing and reducing conditions, it is possible that the strontium was leached out of the granitic rocks and redeposited in stream sediments or minor addition from the basic dykes; 411 to $531 \mathrm{ppm}$ as well as the Hammamat sediments; 41 to $50 \mathrm{ppm}$ (El Balakssy, 2012).

Furthermore, the studied stream sedimentary samples commonly show slightly low REE contents compared with the granitic rocks of the studied area. It ranges from 65 to $223 \mathrm{ppm}$, whereas the granitic rocks show REE contents ranging between 276 and 344 ppm (El Balakssy, 2012). The depletion of REE in these sediments is probably results from the mobilization process by groundwater circulation, dilution of REE by mixing with sediments and/or reworked weathered granitic rocks (Sanematsu et al., 2009). The result is confirmed by markedly good correlation with the chemically measured $\mathrm{U}$ but not with $\mathrm{Th}$ (Figs. $4 \mathrm{i} \&$ j.). Another results showed that the deeper sedimentary samples are relatively enriched with REE; up to 223 ppm than surface samples; up to $65 \mathrm{ppm}$ which may have also been reflected the mobility of some REE towards the subsurface portion and indicating potential for mineralization.
Consequently, the remarkable depletion or addition in certain element indicates the disturbance in the dynamic equilibrium of the elemental concentrations system, leading to local changes in the stream ecosystem balance, where some elements are greatly increased on the expense of others. Dissanayake et al (2000) stated that the enrichment or depletion in certain elements reflects the geology, geochemistry and mineralogy of the source regions and considered a function of a complex series of interactions between hydrothermal fluids, host rocks, groundwater and surface waters.

\section{RADIOACTIVITY}

The chemically and radiometrically measured uranium and thorium contents reveal that the studied stream sediments are much enriched in thorium over uranium (Table 3 ). The average content of chemically- $U$ is as much as $15 \mathrm{ppm}$, while Th exceeds $65 \mathrm{ppm}$ may be due to the relative enrichment of thorium-bearing minerals. Meanwhile, the fresh younger granites of the study area have average content of chemically-U and Th as $25 \mathrm{ppm}$ and $45 \mathrm{ppm}$ respectively (El Balakssy, 2012).

Additionally, the calculated $\mathrm{eU} / \mathrm{U}$ and $\mathrm{eTh} / \mathrm{U}$ ratios (Table 3 ) are mostly more than unity revealing that a selective leaching of uranium content compared with the stable thorium during the supergene processes; un-

Table3: The U, Th, Ra and K contents in stream sediments of W. Mayet El Abd

\begin{tabular}{|c|c|c|c|c|c|c|c|c|c|c|c|}
\hline \multirow{12}{*}{ 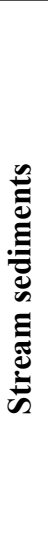 } & \multirow{2}{*}{ Depth } & \multirow{2}{*}{ S.No. } & \multicolumn{4}{|c|}{$\gamma$-ray spectrometry } & \multicolumn{2}{|c|}{$\begin{array}{c}\text { Chemical } \\
\text { measurements }\end{array}$} & \multicolumn{3}{|c|}{ Calculated } \\
\hline & & & $\begin{array}{r}\mathrm{eU} \\
(\mathrm{ppm})\end{array}$ & $\begin{array}{r}\text { eTh } \\
(\mathrm{ppm})\end{array}$ & $\begin{array}{r}\text { eRa } \\
(\mathrm{eU} \text { ppm) }\end{array}$ & $\begin{array}{r}\mathrm{K} \\
(\%)\end{array}$ & $\begin{array}{r}\mathrm{U} \\
(\mathrm{ppm})\end{array}$ & $\begin{array}{r}\text { Th } \\
(\mathrm{ppm})\end{array}$ & $\begin{array}{l}\mathrm{eU} / \mathrm{U} \\
\text { ratio }\end{array}$ & $\begin{array}{r}\mathrm{eTh} / \mathrm{U} \\
\text { ratio }\end{array}$ & Ua \\
\hline & \multirow{5}{*}{ 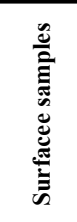 } & $1 \mathrm{a}$ & 13 & 25 & 6 & 3.38 & 10 & 70 & 1.3 & 2.5 & -13.3 \\
\hline & & $2 a$ & 16 & 31 & 7 & 3.72 & 15 & 72 & 1.9 & 2.1 & -9.0 \\
\hline & & $3 a$ & 13 & 23 & 7 & 3.65 & 11 & 81 & 1.2 & 2.1 & -16.0 \\
\hline & & $4 a$ & 15 & 27 & 6 & 3.83 & 14 & 88 & 1.1 & 1.9 & -15.0 \\
\hline & & $5 a$ & 18 & 25 & 5 & 2.79 & 16 & 57 & 1.1 & 1.6 & -3.0 \\
\hline & \multirow{5}{*}{ 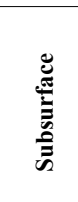 } & 1b & 20 & 23 & 5 & 3.55 & 18 & 66 & 1.1 & 1.3 & -4.0 \\
\hline & & $2 b$ & 19 & 25 & 6 & 3.65 & 17 & 71 & 1.4 & 1.5 & -6.6 \\
\hline & & $3 b$ & 21 & 25 & 7 & 3.3 & 19 & 52 & 1.0 & 1.3 & 1.7 \\
\hline & & $4 b$ & 19 & 22 & 5 & 2.4 & 16 & 49 & 1.2 & 1.4 & -0.3 \\
\hline & & $5 \mathbf{b}$ & 24 & 26 & 6 & 3.55 & 22 & 43 & 1.1 & 1.2 & 7.7 \\
\hline
\end{tabular}


der favorable $\mathrm{pH}$ conditions. The obtained results coincide with the fact that reached by Hansink (1976) and Dardier (2006), where the greater $\mathrm{eU} / \mathrm{U}$ and $\mathrm{eTh} / \mathrm{U}$ ratios indicate recent $\mathrm{U}$ loss. Also, the reverse relationships between the chemically measured $U$ and Th as well as $\mathrm{U}$ and $\mathrm{Th} / \mathrm{U}$ ratio (Fig.5) may corroborate the mobilization of uranium which can be precipitated in the sediments through the pore fluids as authigenic uranium (Algeo and Maynard, 2004 and Rosing and Frei, 2004). According to Wignall and Myers (1988), Jones and Manning (1994) and Tice and Lowe (2006) the authigenic uranium can be calculated from data gathered by the chemical measurements and shown in the formula:

$$
[\mathrm{Ua}]=[\mathrm{U}]-[\mathrm{Th} / 3]
$$

Where: $\mathrm{Ua}$ is the authigenic uranium

$\mathrm{U}$ is the total present $\mathrm{U}$

$\mathrm{Th} / 3$ is equivalent to original $\mathrm{U}$ where $\mathrm{Th}$ is three times as abundant in igneous rocks (Rogers and Adams, 1969).
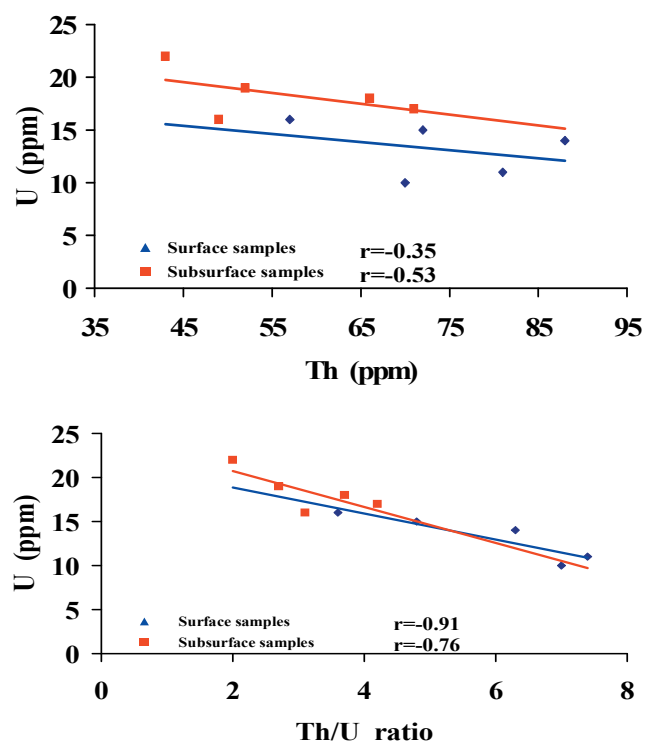

Fig.5: Uranium versus thorium and $\mathrm{Th} / \mathrm{U}$ ratio at different depth levels
Generally, the authigenic U was formed in situ within the depositional site in response to geochemical processes. Their precipitation in sediments indicating chemically reducing conditions but under oxidizing ones leads to remobilization of authigenic $U$. In the present study, such uranium displays negative values that confirm the mobilization of uranium relative to thorium. The leaching leading to disequilibrium is markedly obvious in shallower samples. Remarkably, the highly mobile U6+ could infiltrate downward and trapped by the impermeable silt-size fractions. Here, some of the liberated uranium is mostly reprecipitated as complexes uranium species depending on the anions in the hydrothermal solutions (Azizullah, 1997 and Abdel Monem et al., 1998). Consequently, these sediments appear to be as a slightly favorable delivery pools for thorium rather than uranium which is probably due to either the relative abundance of the thoriumbearing minerals or the selective leaching processes of uranium throughout supergene processes. In agreement with Galindo et al., (2007), Ra probably remains in the sediments with no significant loss.

\section{MINERALOGY}

The obtained results points to the heterogeneous distributions of the heavy minerals content along the stream course, whereas the upland sedimentary samples display total heavy minerals content ranging from $2.44 \%$ to $6.77 \%$ with an average of $4.71 \%$, while it varies from $5.11 \%$ to $8.02 \%$ with an average of $6.44 \%$ in bottom sedimentary samples (Table $4 \&$ Fig. 6). Accordingly, the heavy minerals content tend to be enhanced at the bottom stream, as a result of the significant dilution of the superficial sedimentary samples by seasonally reworked light mineral grains as quartz, mica and feld- 
Table 4: Total heavy fraction in stream sediments of W. Mayet El Abd.

\begin{tabular}{|c|c|c|}
\hline Depth & S.No. & $\begin{array}{r}\text { Total } \\
\text { Heavy } \\
(\%)\end{array}$ \\
\hline \multirow{6}{*}{ 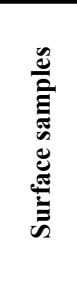 } & $1 \mathrm{a}$ & 2.44 \\
\hline & $2 a$ & 4.81 \\
\hline & $3 a$ & 4.25 \\
\hline & $4 a$ & 5.26 \\
\hline & $5 a$ & 6.77 \\
\hline & Av. & 4.71 \\
\hline \multirow{6}{*}{ 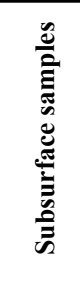 } & $1 b$ & 5.11 \\
\hline & $2 b$ & 6.12 \\
\hline & $3 b$ & 5.51 \\
\hline & $4 b$ & 7.43 \\
\hline & $5 b$ & 8.02 \\
\hline & Av. & 6.44 \\
\hline
\end{tabular}

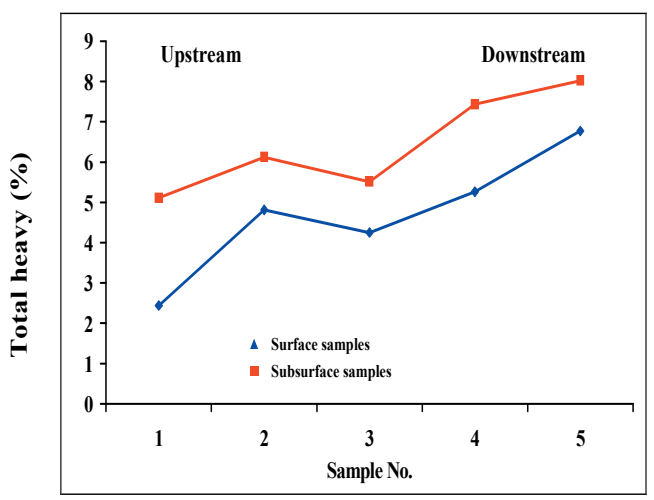

Fig 6: Lateral distribution of the total heavy fraction in stream sediments of W. Mayet El Abd

spars during flash floods. Likely, the variation in the heavy minerals content; changes the sedimentary regime as a function of the energy of the stream during sedimentation, whereas the downstream samples attain high contents of total heavy minerals than the upstream ones (Fig. 6). This is due to either an erosional remnant of the bordering granites and Hammamat molasses terrenes of Wadi Mayet El Abd are which formed as a result of the high energies of depositional agents; high stream discharge; or drained from the further reaches which are represented by the nearby weathered sediments of Wadi Belih at downstream sites.

Further, the markedly positive relationship between the total heavy minerals and $\mathrm{U}$ as well as exactly negative trend with thorium (Fig.7) support a relative intimate coherence to $\mathrm{U}$ and imply their abundance in bottom sediments as well as downstream.
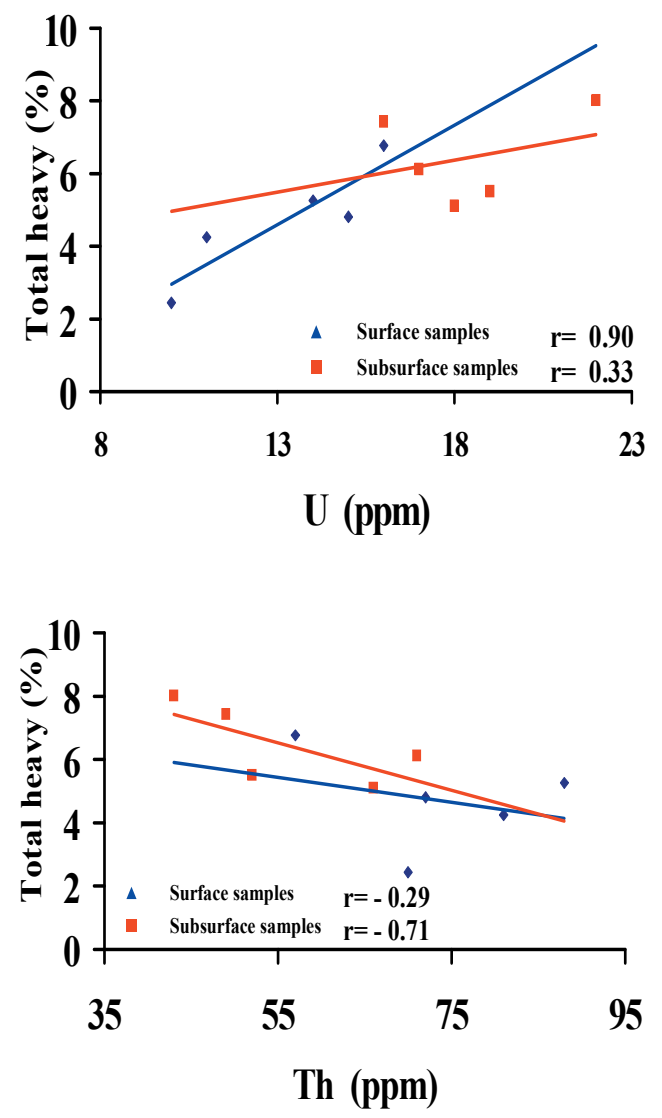

Fig.7. Total heavy minerals versus chemically measured uranium and thorium 
The mineralogical studies are carried out to characterize the accessory mineral assemblages that responsible for the radioactivity on the studied stream sediments. Consequently a conspicuous variety of the uraniferous accessory minerals as well as primary thorium minerals have been established. Essentially, the XRD should have taken place on the common minerals, while ESEM is used as a complementary technique for characterizing the rarity ones. In addition, the frequencies of these minerals in the examined samples (sand size $<0.5 \mathrm{~mm}$ ) at different depth levels were calculated and the average contents were summarized in Table (5) and graphically represented on Figs. (20\&21). Consequently, the identified radioactive minerals are briefly described in the following paragraphs.

\section{Uranium Accessory Minerals}

The microscopic study revealed that the uranium accessory minerals as betafite, ishikawaite, xenotime, violet fluorite and zircon are mostly responsible for the radioactivity of the studied stream sediments. The betafite and ishikawaite minerals are the common niobate minerals. The abundance of these minerals is correlated with the niobium concentrations which show a moderately values, those varies from 42 $\mathrm{ppm}$ to $50 \mathrm{ppm}$ in surface samples, whereas in subsurface ones it detected between 39 ppm and 48 ppm.

\section{Betafite (Ca, U) ${ }_{2}(\mathrm{Ti}, \mathrm{Nb}, \mathrm{Ta}, \mathrm{Fe})_{2} \mathrm{O}_{6}(\mathrm{OH})$}

Betafite is uranyl titanate mineral, assigned to primary $U$ minerals and exhibits a black appearance. The EDX identify the composition of betafite (Fig.8). It contains high concentration of $\mathrm{Nb}, \mathrm{Ti}$, and fair amount of U, Ta and REE. Moreover, a well developed betafite crystals with highly pitted surface being common and visually observed through BSE image. Such feature is probably due to the weathering effect. The X-ray diffraction pattern of betafite is shown on Figure (9). Betafite is rare in the study area; it is more abundant in subsurface samples than surface one; $0.003 \%$ and $0.002 \%$, respectively.

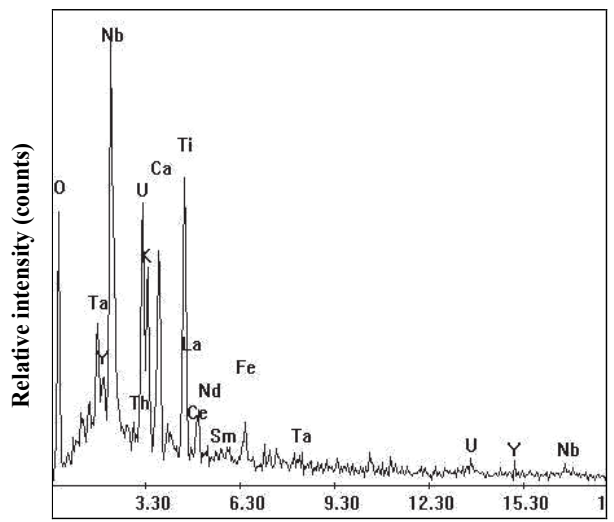

Energy (keV)

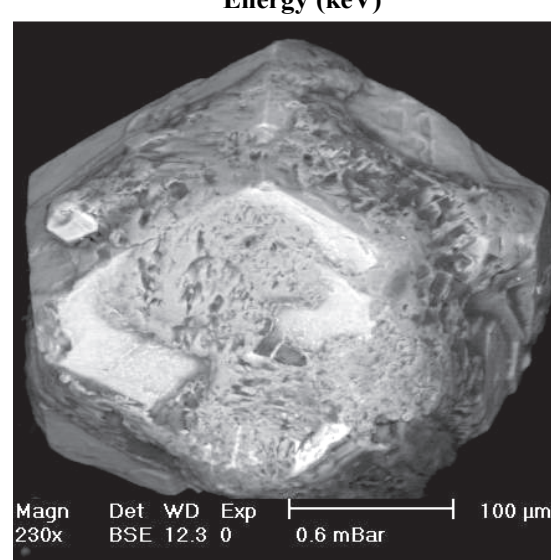

Fig. 8: EDX and BSE image showing discrete crystal of betafite.

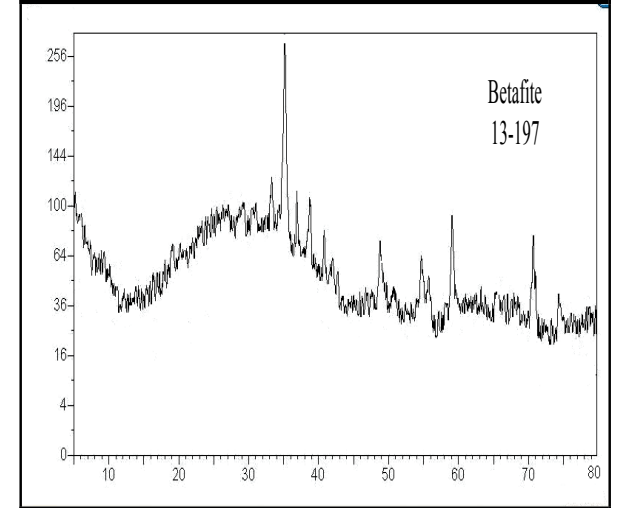

Fig. 9: Distinct X-ray diffraction pattern of betafite mineral. 


\section{Ishikawaite $(\mathrm{U}, \mathrm{Fe}, \mathrm{Y})_{2}(\mathrm{Nb}, \mathrm{Ta})_{2} \mathrm{O}_{4}$}

Ishikawaite is the main variety of samarskite group that exhibits significant amount of uranium. Commonly, it is noticed as reddish brown platy smooth crystals. It represents mostly of $0.001 \%$ and $0.004 \%$ in superficial and bottom samples, respectively (Table 5). Furthermore, the relative semi-quantitive ESEM-EDX microanalysis carefully revealed up to $22.97 \mathrm{wt} \%$ of $\mathrm{U}$ related to $\mathrm{Nb} ; 32.34$ wt. \% within the typical range in ishikawaite (Fig.10). Raslan (2008) mentioned that ishikawaite examined from Abu Rushied gneissose granite has assay of about $50 \% \mathrm{Nb}_{2} \mathrm{O}_{5}$ and $26 \% \mathrm{UO}_{2}$.

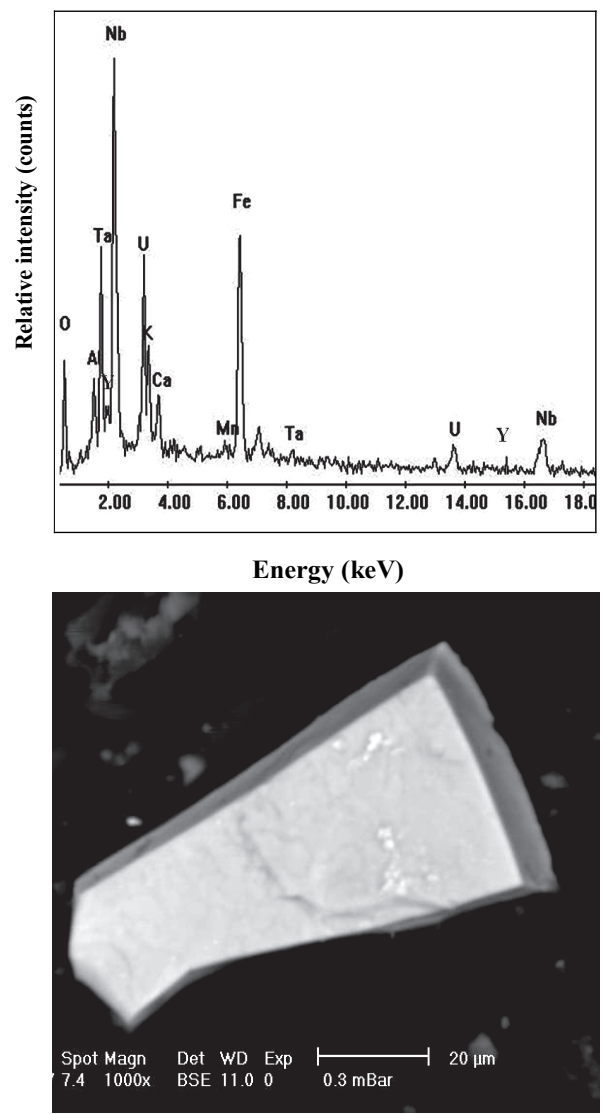

Fig. 10 EDX and BSE image showing uranium-rich samarskite; ishikawaite

\section{Xenotime (HREE, Y, $\mathrm{PO}_{4}$ )}

Compositionally, xenotime was found to consist mostly of Y plus HREE phosphate, it was observed as brown to greenish brown colors and occurs as granular aggregates. In the present study, it comprises $0.003 \%$ in surface samples that slightly exceeds to $0.004 \%$ in subsurface one (Table5). The existence of xenotime may be related to abundance of their main component as yttrium content which displays elevated concentrations in subsurface stream samples; it is marked by $244 \mathrm{ppm}$ to $621 \mathrm{ppm}$ rather than surface stream sample which vary from $358 \mathrm{ppm}$ to $497 \mathrm{ppm}$. EDX microanalysis shows traces of Si replacing P. Moreover, the BSE observations reveal that the stubby xenotime crystals exhibit subparallel intergrowths similar to zircon (Fig.11). The bipyramidal shape of detrital xenotime grains indicates formation at a high temperature, which was mostly sourced from granitic rocks (Subrahmanyam et al., 2004 and Rosa et al, 2010). Knowing that, xenotime may have formed from coffinite due to substitution of Y and $\mathrm{P}$ for $\mathrm{U}$ and $\mathrm{Si}$, respectively (Evins and Jensen 2010). El Balakssy (2012) reported that coffinite $\left(\mathrm{USiO}_{4} \cdot \mathrm{nH}_{2} \mathrm{O}\right)$ was recorded in Mayet El Abd area as a result of the replacement of uraninite by silica-rich hydrothermal solutions under reducing conditions; a process known as coffinitization.

\section{Fluorite $\mathrm{CaF}_{2}$}

Fluorite is chiefly recorded in the granitic rocks as well as the stream sediments of the study area as radioactive-bearing accessory minerals. EDX spectra demonstrate that, fluorite significantly enriched with REE and Y (Fig.12). In the present study, fluorite exhibits slightly high frequency in the subsurface samples than the surface one; $0.022 \%$ and $0.020 \%$, respectively (Table 5). Nevertheless, the blue variety is the most common; it has intimate association with the secondary uranium mineralization in all the U-bearing granites in Egypt (Raslan, 2009). Usually, the presence of fluorite suggests the epigenetic hydrothermal vein type origin of the uranium mineralization (Sarcia, 1958 and Roze, 1994). 

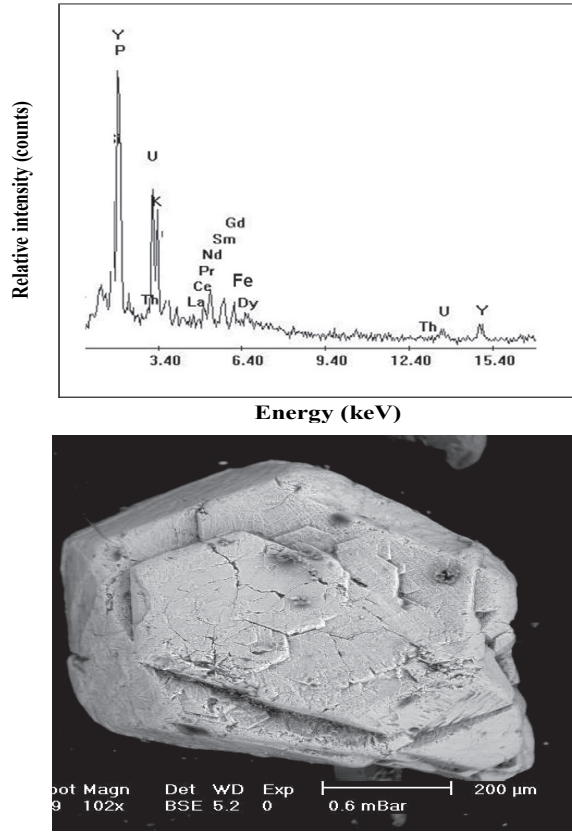

Fig. 11. EDX and BSE image showing stubby xenotime crystal has subparallel intergrowths
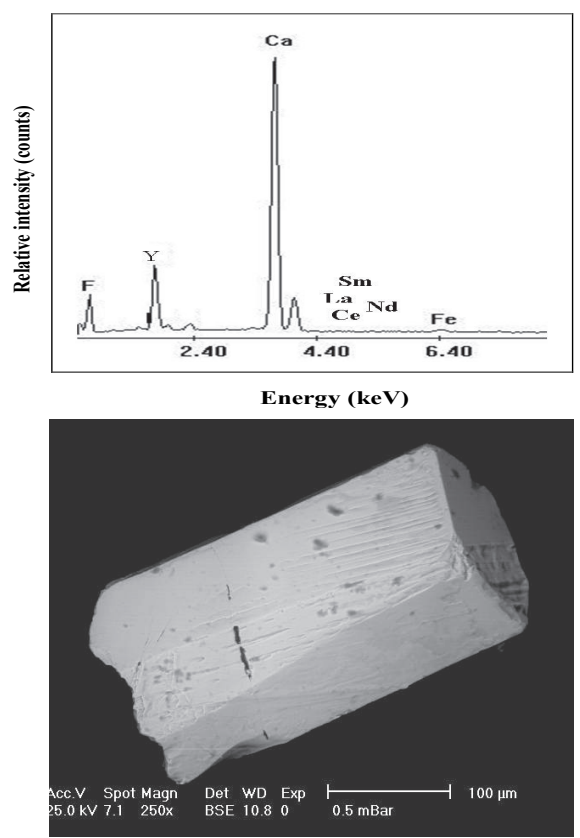

Fig. 12. EDX and BSE image showing REE bearing fluorite

\section{Zircon $\mathrm{Zr} \mathrm{SiO}_{4}$}

Zircon is locally common in the studied stream sediments as radioactive-bearing accessory minerals due to their resistant for weathering. Zirconium is the main constituent in zircon, it is greatly increased with depth, where the upland sediments exhibit significant $\mathrm{Zr}$ content, varies from $594 \mathrm{ppm}$ to $814 \mathrm{ppm}$, while the deeper sedimentary samples have a wide range of $\mathrm{Zr}$; between $435 \mathrm{ppm}$ and 1005 ppm. Consequently, the highly enriched $\mathrm{Zr}$ content is mainly attributed to the abundance of zircon in the studied sediments. Whereas, it is relatively frequent in subsurface samples than the surface one; $0.017 \%$ and $0.012 \%$, respectively (Table 5). Zircon is a significant host for REE, Th, and U (Finch and Hanchar, 2003 and El Balakssy, 2010).

Mostly, the studied zircon occurs as excellent idiomorphic crystals. It displays various color appearance ranges from yellow to brown and cloudy. The water clear of zircon grains is relatively rare. The moderate and high elongated zircon grains are predominating, where it displays average elongation ratio $(\mathrm{L} / \mathrm{B})$; varies between 2.5 and 4.0 that may reflects the derivation from nearby sources. Zoning is slightly common, the inclusions and twinning are rare and the microfractures have been noticed in different direction may be due to the tectonic effect on the host rocks. The slight modification of the habit of W. Mayet El Abd zircon may be due to abrasion during transportation.

The present study confirms the preferential association between zircon and thorite minerals, whereas thorite is isostructural with zircon. Thus, different distinctive features of zircon and thorite are observed through the BSE image. Figure (13) illustrates the presence of outgrowth of primary radioactive mineral; mainly uranothorite on prismatic bipyramidal zircon crystal. Unlike, metamictized thorite was found to be as an overgrown by subhedral zircon crystal (Fig.14). In contrast, overgrowth of anhedral thorite crystal on wellfaced zircon crystal was clearly visible in the BSE image (Fig.15). 


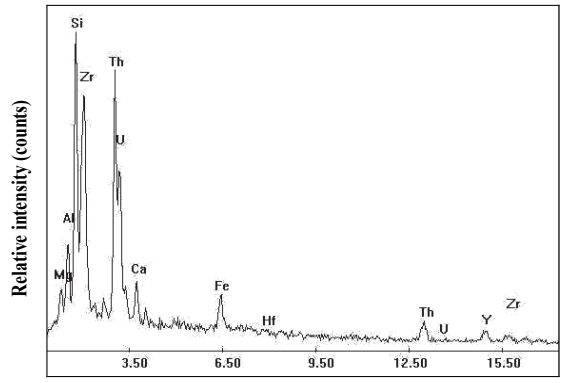

Energy (keV)

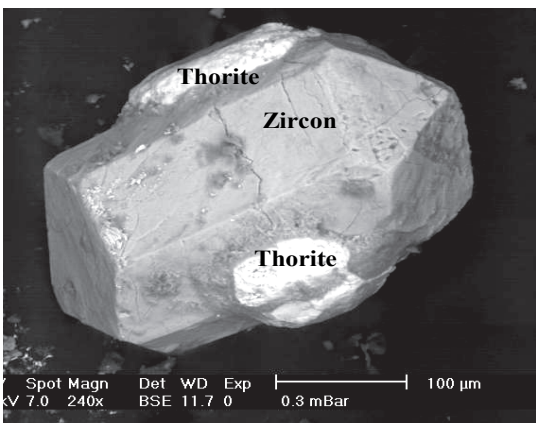

Fig. 13. EDX and BSE image showing outgrowth of primary radioactive mineral; uranothorite along idiomorphic zircon grain
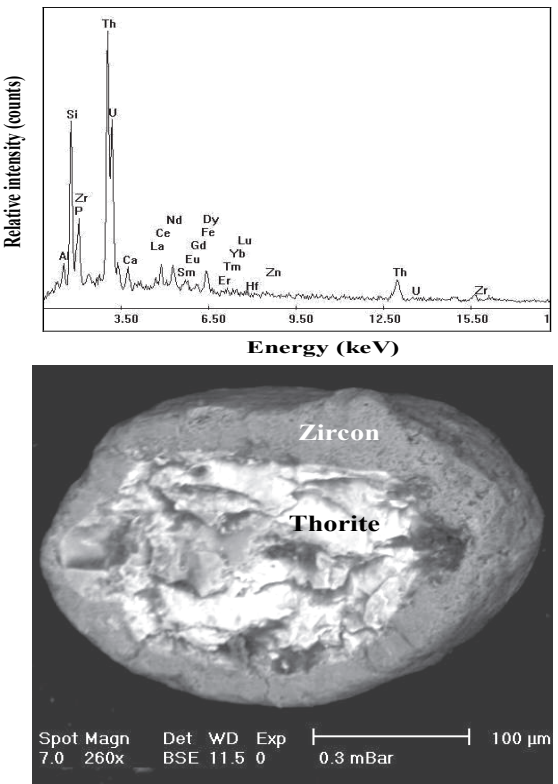

Fig. 14. EDX and BSE image showing overgrowth of subhedral zircon crystal on metamectized thorite
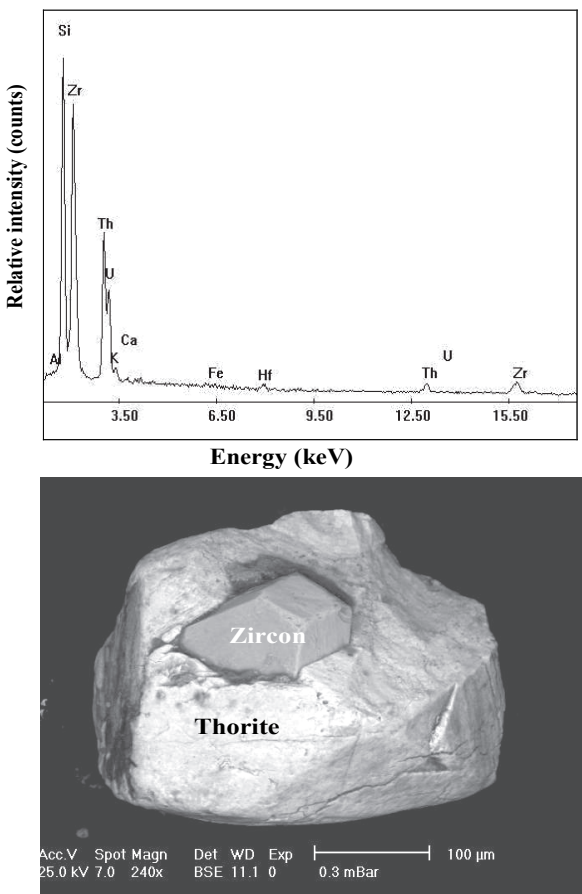

Fig. 15. EDX and BSE image showing overgrowth of thorite on well-faced zircon crystal

Such association suggests the limited solid solution series, which is probably due the low coupled substitution between $\mathrm{Zr}^{4+}$ and $\mathrm{Th}^{4+}$. This faint substitution is supported by the obtained concept; very weakly positive correlation between $\mathrm{Zr}$ and $\mathrm{Th}$, where $\mathrm{r}=0.16$ (Fig, 4f). Despite of the substitution implies that zircon is weakly carrier of Th but may leading to changes in the physical properties of zircon, metamictization and fluorescence (Wopenka et al., 1996 and Nasdala et al., 2003 and El Balakssy, 2010).

\section{Thorium Minerals}

Thorite, uranothorite and monazite have been established as the most common resistant thorium minerals. Thorite and uranothorite are primary minerals of thorium. Thorium content has moderate values in studied sediments; varies from $57 \mathrm{ppm}$ to $88 \mathrm{ppm}$ in surface samples while it varies from $43 \mathrm{ppm}$ to $71 \mathrm{ppm}$ in bottom sediments. Consequently, the slightly enriched thorium content is mainly attributed to the fair abundance of uranothorite in the studied sedi- 
ments which was found to be relatively enriched in subsurface samples than the surface ones; $0.06 \%$ and $0.04 \%$ respectively (Table 5 ).

EDX microanalysis illustrating the stoichiometric composition of uranothorite, besides the BSE image which showed that it is mostly found as discrete crystals with cracked structure (Fig.16), their existence may probably relate to the hydrothermal veins. Likewise, uniqueness features representing accessory uranothotite that stained by shrinkage cracks of iron (Fig.17). The marked association of uranothorite and iron were identified by localized Fe-peak, mainly hematite that being seen in EDX. The distinct Fe is probably due to hematization that dominated in the study area (El Balakssy, 2012). On the other hand, monazite was found as euhedral particles that exhibits inclusion of zircon (Fig.18). Conversely, clusters of botryoidal monazite crystals are being clearly visible as filling zircon microfractures (Fig.19). The study revealed that monazite is relatively abundant in surface sample than the subsurface one; $0.004 \%$ and $0.003 \%$, respect ively(Figs.20\&21). Eventually, pronounced barite admixed on zircon crystal is visually recorded though BSE reveals the greatly enriched of $\mathrm{Ba}$ in the studied area (Fig.22); Ba varies from 995$1175 \mathrm{ppm}$.
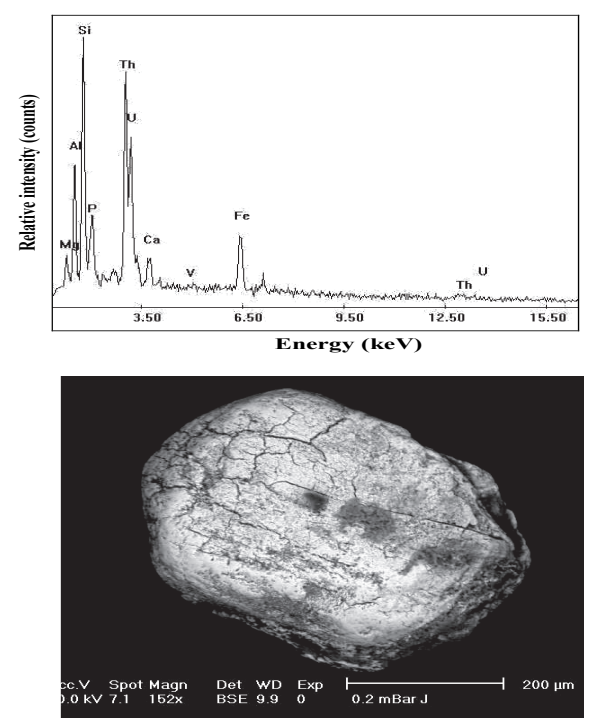

Fig. 16. EDX and BSE image showing discrete crystal of thorite
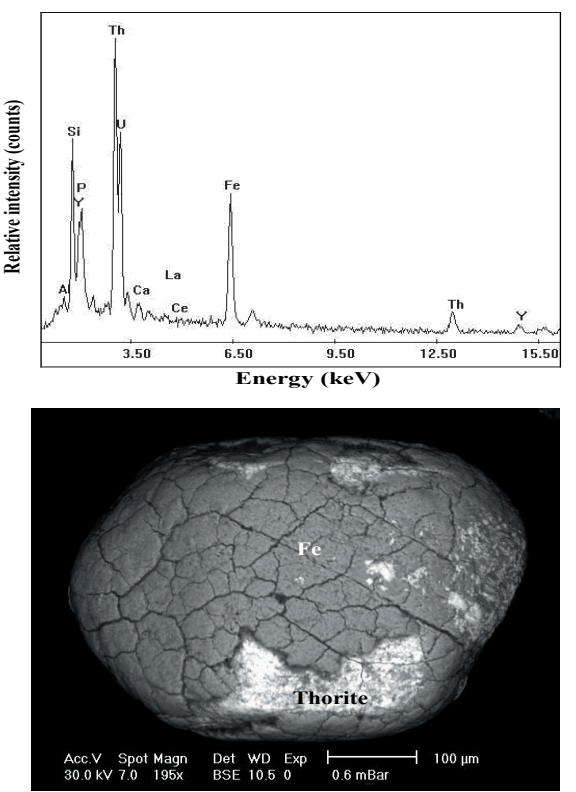

Fig. 17. EDX and BSE image showing uranothorite grain stained by shrinkage cracks of iron
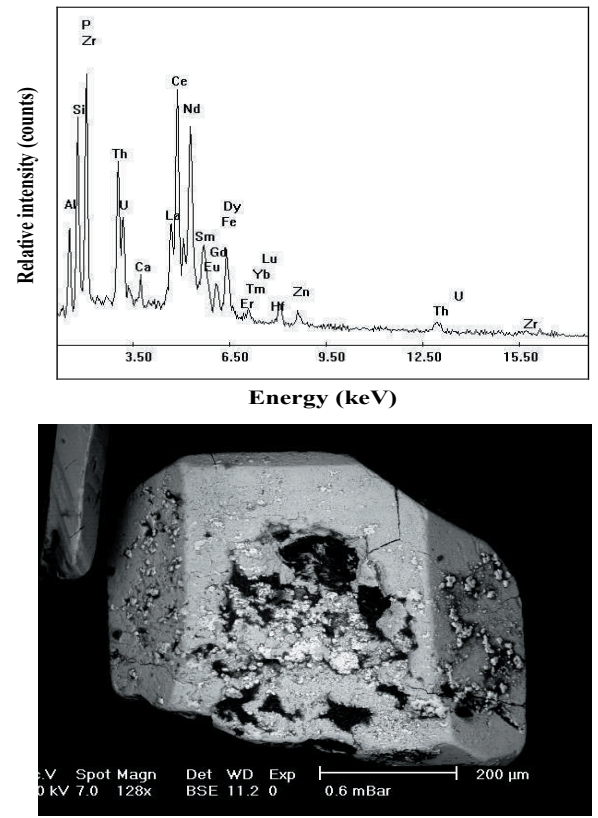

Fig. 18. EDX and BSE image showing euhedral monazite grains 


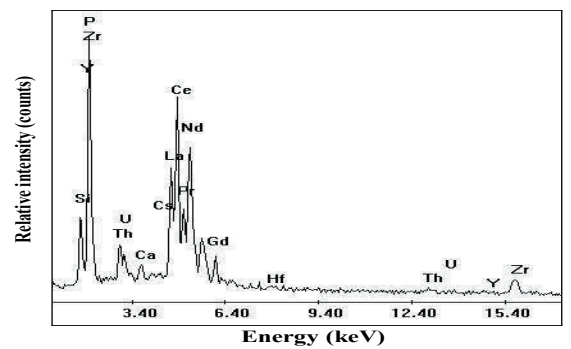

Table 5: Frequencies of the recorded accessory radioactive minerals in the Sand size $<0.5 \mathrm{~mm}$ of the studied sediments at different depth levels.

\begin{tabular}{l|r|r|r}
\hline \multirow{2}{*}{ Mineral } & Chemical & $\begin{array}{r}\text { Percentage } \\
\text { Name }\end{array}$ & $\begin{array}{r}\text { Percentage } \\
(\%)\end{array}$ \\
\cline { 3 - 4 } & formula & $\begin{array}{r}\text { Surface } \\
\text { samples }\end{array}$ & $\begin{array}{r}\text { Subsurface } \\
\text { samples }\end{array}$ \\
\hline Betafite & $(\mathrm{Ca}, \mathrm{U})_{2}(\mathrm{Ti}, \mathrm{Nb}, \mathrm{Ta}$, & 0.002 & 0.003 \\
& $\mathrm{Fe})_{2} \mathrm{O}_{6}(\mathrm{OH})$ & & \\
Ishikawaite & $(\mathrm{U}, \mathrm{Fe}, \mathrm{Y})_{2}\left(\mathrm{Nb}, \mathrm{Ta}_{2} \mathrm{O}_{4}\right.$ & 0.001 & 0.004 \\
Xenotime & $\mathrm{YPO}_{4}$ & 0.003 & 0.004 \\
Fluorite & $\mathrm{CaF}_{2}$ & 0.020 & 0.022 \\
Zircon & $\mathrm{Zr} \mathrm{SiO}_{4}$ & 0.012 & 0.017 \\
Uranothorite & $\mathrm{U}, \mathrm{Th} \mathrm{SiO}_{4}$ & 0.004 & 0.006 \\
Monazite & $\mathrm{REE}, \mathrm{P}$ & 0.004 & 0.003 \\
\hline
\end{tabular}

Traces: $<0.005$

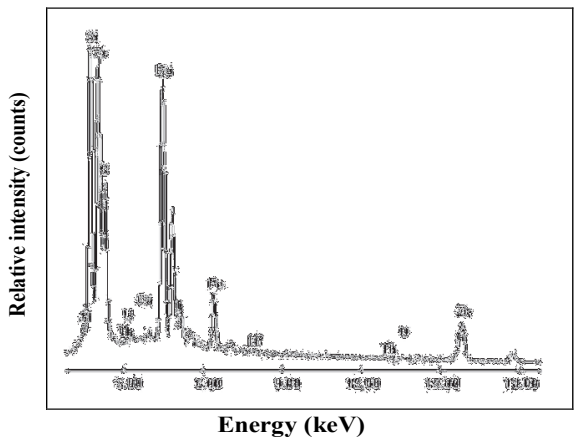

Fig. 19. EDX and BSE image showing clusters of botryoidal monazite crystals are clearly visible as filling zircon microfractures

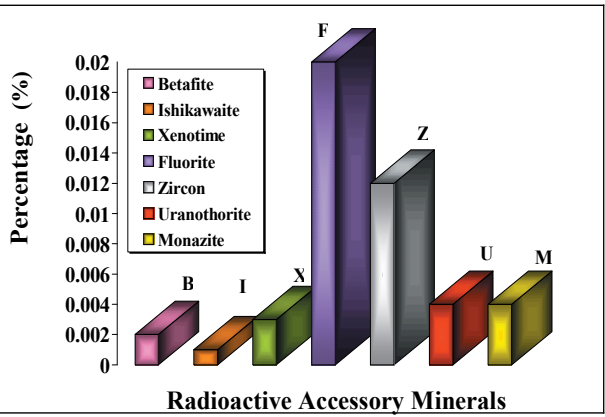

Fig.20: Frequency of accessory radioactive minerals in surface sediments

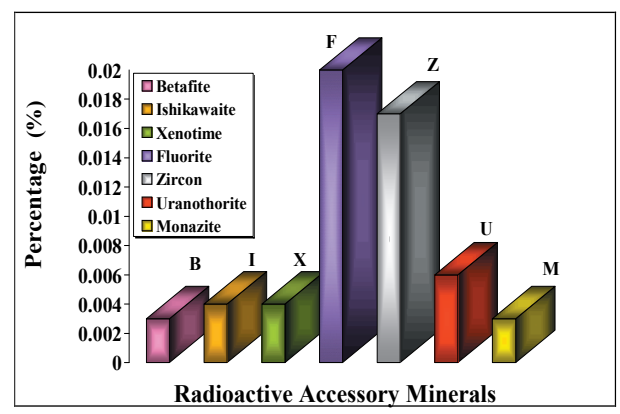

Fig.21: Frequency of accessory radioactive minerals in subsurface sediments

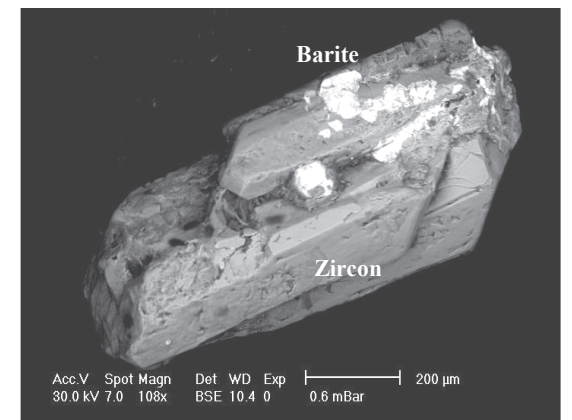

Fig. 22 . EDX and BSE image showing ubiquitous barite bearing zircon

\section{CONCLUSIONS}

W. Mayet El Abd is located in the northern part of G. Gattar, north Eastern Desert of Egypt. The available database points to the heterogeneous distributions of the heavy minerals content along the stream course, which 
tend to be enhanced at the bottom stream, as a result of the accumulation of the seasonally reworked light particles in upland sites. It is also markedly enriched in downstream due to the high energies of depositional agents and reworking of the sediments. These sediments appear to be as a slightly favorable delivery pools for thorium rather than uranium which is probably due to either the abundance of the thorium-bearing minerals or the selective leaching of uranium throughout supergene processes. Such liberated uranium can be reprecipitated as a complexes uranium species. The $\mathrm{eTh} / \mathrm{U}$ and eU/U ratios are mostly above unity, the negative values of the calculated authigenic uranium, the markedly reverse relationships between uranium and thorium as well as uranium and $\mathrm{Th} / \mathrm{U}$ ratio reveal the disequilibrium state of uranium and confirm $U$ leaching. On such way, the markedly positive relationships between $U$ and the total heavy fraction as well as some trace elements; notably $\mathrm{Rb}$ and REE may suggest common sources with $\mathrm{U}$ but not with Th. Conversely, the good negative relationships between $\mathrm{U}$ and both $\mathrm{Ba}$ and $\mathrm{Nb}$ reflect the mobile nature of $\mathrm{U}$ against the immobility of $\mathrm{Ba}$ and $\mathrm{Nb}$. Likely, the absence of clear coherence between $\mathrm{Zr}$ and both $\mathrm{U}$ and $\mathrm{Th}$ have been recorded.

In addition, it is clear that in the concerned stream sediments act also as a powerful sink for the radioactive accessory minerals as well as other rare earth minerals that may control the geochemical enrichment of elements, as; $\mathrm{U}$, Th, Zr, Y, Nb, REE, Ba, Zn, and V. Thus, SEM/EDX-BSE revealed that the minerals; betafite, ishikawaite, xenotime, violet fluorite and zircon have been identified as the principal constituents of the uranium accessory minerals in the concerned stream sediments; whereas monazite dominates as thorium-bearing minerals. Moreover, thorite and uranothorite have also been recognized at lower concentration magnitude. The enriched concentrations of REE in the sediments are due to the presence of monazite, xenotime, fluorite and zircon. Furthermore, the enrichments of $\mathrm{Nb}, \mathrm{Y}$ and
$\mathrm{U}$ can be attributed to the occurrence of niobate minerals; betafite and ishikawaite which acts as a sink for these elements. Likely, the presence of minerals such as thorite, monazite and uranothorite accounts for the enrichments in thorium. $\mathrm{Zr}$ is related to the abundance of zircon. The depletion in base metals $(\mathrm{Ni}, \mathrm{Cu})$ is presumably due to the absence of the basic rocks in the study area.

A particular attention has to be given to the potential of the radionuclides and rare elements in the accessory minerals, despite of their frequency in the whole stream sediments. In conclusion, the study sediments are conceivably genetically related to common sources. Hence, they may represent an erosional remnant either of the bordering granites and Hammamat molasses sediments of Wadi Mayet El Abd or drained from further reaches such as the nearby weathered sediments of Wadi Beli at downstream site.

\section{Acknowledgements}

The author is sincerely grateful to Prof. Dr. A.M. El-Kammar, Department of Geology, Faculty of Science, Cairo University, Egypt for his accurate reviewing in earlier version of this manuscript. Also, deep thanks and gratitude to Prof. F.S. Bakhit, N.M.A, Egypt for critically reviewing and improving the final version of the manuscripts. Special thanks are extended to Prof. Dr. D.M, El Kholy and Dr. Hassan El Sandoly, N.M.A., Egypt during sample collections.

\section{REFERENCES}

Abdel-Monem,A.A., El Amin,H.M., El Afandy,A. H., Hussein,H.A. and Abdel Aty, M.A.,1998. Petrological and geochemical characteristics of some younger granites bearing U- mineralization; recognition criteria of uranium province in Egypt. Proc. Egypt Acad. Sci.,48, 213-270.

Abu Bakr, A. M., El Balakssy, S.S., Moriyama, T., Sadek A A. and Hassan, A. H. ,2007. Sedimentological and mineralogical investigations on Wadi El Sybaaya alluvial deposits, 
Southern Sinai, Egypt. J. Mineral. Soc. Egypt. The Egyptian Mineralogist, National Research Center., Egypt. (in press)

Abu Zaid, M, M., 1995. Relation between surface and subsurface uranium mineralization and structural features. Gabal Qattar, north Eastern Desert, Egypt. M.Sc. Thesis, Fac. Sci., Ain Shams Univ., 208 p.

Algeo, T.J. and Maynard, J.B.,2004. Trace-element behaviour and redox facies in core shales of Upper Pennsylvanian Kansas-type cyclothems. Chem. Geol., 206, 289-318.

Attawiya, M.Y.,1990. Petrochemical and geochemical studies of granitic rocks from Gabal Gattar area, Eastern Desert, Egypt, Arab. J. Nucl. Sci. App., Cairo, 23, (2),13-30.

Azizullah, 1997. Petrotectonics, petrology and genesis of uranium mineralization of Siwalik group of Thatti Nasrati and Shavah-Shanawah area, $\mathrm{Ph}$ D. Thesis, Punjab, Univ., Lahore.256p.

Bishta, A.Z.,2004. Lithological discrimination of Gabal Gattar-Um Disi environs, North Eastern Desert of Egypt using thematic mapper data of Landsat-7. Proc. 3rd. Int. Symp. Geophysics, Tanta Univ., 541-557.

Dardier,A.M.,2006. Geology, petrology and radioactivity of the older granitoids and younger granites of Gabal El-Umrah area, Central Eastern Desert, Egypt. Delta.J. Sci., .30, part III,116.

Dissanayake, C.B., Chandrajtth, R. and Tobschall, H.J.,2000. The geology, mineralogy and rare element geochemistry of the gem deposits of SriLanka. Bull. Geol. Soc. Finland. 72, Parts $1-2,5-20$.

El Balakssy, S.S.,2006. Minerals controlling the radioactivity in the stream sediments at Wadi El Shallal area, South Western Sinai, Egypt. J. Sedimentology of Egypt, Cairo, 14, 243- 260.

El Balakssy, S.S.,2010. Zircon zonation from Egyptian coastal sediments as genetical indicator, J. Mineral. of Egypt. The Egyptian Mineralogist
,Notional Research Center, Cairo, Egypt. (in press)

El Balakssy, S.S.,2012. Mineralogy of the radioactive occurrence at the northern periphery of Gabal Gattar granites, North Eastern Desert, Egypt. Nucl. Sci. scientific J., Egypt. (in press)

El Bouhy S.M.S.,1997. Investigation of secondary dispersion of $U$ and Mo in wadi sediments of Gabal Gattar-Abu Harba area: and its application to geochemical prospection in arid zones. M.Sc. Thesis, Ain Shams Univ., Fac. Sci., Cairo, Egypt. p 174.

EL Kammar, A.M., Salman, A.E., Shalaby, M.H. and Mahdy, A.I. ,2001. Geochemical and genetical constraints on rare metals mineralization at the Central Eastern Desert of Egypt. J. Geoch.,35, 117-135.

El Rakaiby, M.L. and Shalaby, M.H.,1992. Geology of Gabal Gattar batholith, Central Eastern Desert, Egypt, Int. J. Remote Sensing, 13(12), 2337-2347.

El Zalaky, M. A.,2007. Geology and remote sensing studies on some uranium-bearing granites, Eastern Desert, Egypt. Ph.D. Thesis, Fac. Sci, Banha Univ, Egypt. 205 p.

Esmail, E. M.,2005. Subsurface geological constraints controlling uranium mineralization at the northern part of Gabal Gattar, north Eastern Desert, Egypt. Ph.D. Thesis, Fac. Sci., Ain Shams Univ., Cairo, Egypt, 250 p.

Evins, L.Z and Jensen, K.A.,2010.Coffinitization of uraninite-a review and discussion of observations on different scales.

Finch, R. J. and Hanchar, J. M. ,2003. Structure and chemistry of zircon and zircon-group minerals. Reviews in Mineralogy, (Hanchar, J. M. and Hoskin, P. W. O., eds.), 53, 1-25.

Galindo, C., Mougin L., Fakhi, S., Nourreddine, A.N., Lamghari, A. and Hannache,H. ,2007. Distribution of naturally occurring radionuclides (U,Th) in Timahdits black shale (Morocco),J. of Environ. Radioactivity, 92,41-54. 
Hansink, J. D.,1976. Equilibrium analysis of a sandstone roll front uranium deposit, In:Explotation for uranium ore deposites: Inter, A.E.A., Viena, 683-693.

Hassaan A.H.,1999. Geomorphological studies of drainage basins with emphasis to radioactive minerals in Northern Eastern Desert, Egypt. M.Sc. Thesis, Fac.Sci.,Ain Shams Univ. 217p.

Jones, B. and Manning, D.A.C.,1994. Comparison of geochemical indices used for the interpretation of palaeoredox conditions in ancient mudstones. Chem. Geol., 111, 111-129.

Mahdy, M. A., Salman, A. B. and Mahmoud, A. H.,1990. Leaching studies on the uraniferous Hammamat sediments, Wadi Bali, Northern Eastern Desert, Egypt. 14th Cong. Min. \& Metall., Edinburgh Scotland, 229-235.

Nasdala, L., Zhang, M., Kempe, U., Panczer, G., Gaft, M., Andrut, M. and Plotze, M., 2003. Spectroscopic methods applied to zircon;Reviews in Mineralogy and Geochemistry, 53, 427-467.

Nossair, A.A.,2005. Geological factors controlling uranium distribution and affecting its localization in G-II occurrence, Gabal Gattar, NED, Egypt, M.Sc. Thesis, Fac. Sci., Zagazig Univ., Benha,. 179 p.

Nossier, L. M.,1996. U-F bearing episyenitized "desilicified" granitic rocks of Gabal Gattar, north Eastern Desert, Egypt. Egypt. Acad. Sci., 46,375-396.

Rankama K. and Sahama T. G.,1950. Geochemistry. University of Chicago Press, 912 p.

Raslan, M.F.,2008, Beneficiation of uranium-rich fluorite from ElMissikat mineralized granite, Central Eastern Desert, Egypt, Physicochemical Problems of Mineral Processing J, 42, 185194.

Raslan, M.F.,2009. Mineralogical and geochemical characteristics of uranium-rich fluorite in El- Missikat mineralized granite, Central Eastern Desert, Egypt GEOLOGIJA 52/2, 213-220, Ljubljana.
Rogers, J.J.W. and Adams, J.S.S.,1969.Uranium.In; Wedepohl, K.H.(ed) Handbookof geochemistry. New York, Springer-verlag, 4, 92B1-91C10.

Rosa,D., Salgueiro, R.,Inverno,C.,Deolivira, D. and Guimar, F.,2010. Occurrence and origin of alluvial xenotime from Central Eastern Portugal (Central Iberian Zone/Ossa-Morena Zone). Comunicaçes Geolgicas, 97, 63-70.

Rose, A.W., Hawkens, H.E. and Webb, J.S.,1979. Geochemistry in mineral exploration (2nd edition). Academic Press, London.

Rosing, M.T. and Frei, R.,2004. U-rich Archaean sea-floor sediments from Greenland - indications of $>3700$ Ma oxygenic photosynthesis, Earth and planetary Science Letters, 217, 237244.

Roz, M. E.,1994. Geology and uranium mineralization of Gebel Gatter area, North Eastern Desert, Egypt, M.Sc.Thesis, Fac. Sci.,Al Azhar Univ., $175 p$.

Salman, A.B., Ali., M.M. and Shalaby, M., H.,1991. Stream sediments survey in Gabal Gattar Umm Dissi granites. Northern Eastern Desert, Egypt

Salman, A.B., Shalaby, M., Nosseir, L., El Kholy, D., Roz, M., Abu Zeid, M., Mostafa, M, Amin, N.,Ayoub, R. and Khamis, H.,1994.Gabel Gattar Prospect, an obvious model of intragranitic uranium mineralization. 2nd Arab Conf. on the Peaceful Uses of Atomic Energy, Cairo, AAEA.

Sanematsu, K., Murakamil, H., Watanabe,Y., Duangsurigna, S . and Vilayhack, S.,2009. Enrichment of rare earth elements (REE) in granitic rocks and their weathered crusts in central and southern Laos Bull. Geol. Surv. Japan, 60 (11/12),527-558.

Sarcia, J. A.,1958. The uraniferous province of northern Limousin and its three principal deposits. Peaceful uses of atomic energy, Inter., Atomic Energy Agency (IAEA) Conf., 2.

Sayyah, T.A. and Attawiya, M.Y., 1990. Contribution to the mineralogy of uranium occurrence 
of Gebel Gattar granites, Eastern Desert, Egypt. Arab J. Nuc. Sci. App. Cairo, 23, No. 1, 171184.

Shalaby, M. H.,1990. Uranium mineralizatrion in northern Gabal Gattar Locality, Northern Eastern Desert, 7th con. Phanerozoic and Develop. Al Azher Univ. Cairo.

Shalaby, M. H.,1995. New occurrence of uranium mineralization G-VII, Gabal Qattar uranium prospect, north Eastern Desert, Egypt. Bull. Fac. Sci. Alex. Univ., 35, No.2,447- 460.

Shalaby, M.H., Bishta, A.Z. Roz ,M.E. and El Zalaky, M.A.,2010. Integration of Geologic and Remote Sensing Studies for the Discovery of Uranium Mineralization in Some Granite Plutons, Eastern Desert, Egypt, JAKU: Earth Sci., 21, No. 1, 1-25.
Subrahmanyam A.V., Desapati, T., Anil Kumar, V., Deshmukh, R.D. and Viswanathan, G.,2004. Occurrence of xenotime in the Narasapur beach placers, West Godavari District, Current); Science, 87-10, 1458-1461.

Tice, M. M and Lowe, D. R., 2006. Hydrogenbased carbon fixation in the earliest known photosynthetic organisms Geology, Geol. Soc. Amer., 34, Issue 1, 37-40

Wignall, P.B. and Myers, K.J., 1988. Interpreting the benthic oxygen levels in mudrocks, a new approach: Geol., 16, 452-455.

Wopenka, B., Jolliff, B.L., Zinner, E., and Crèmes, R., 1996. Trace element zoning and incipient metamictization in a lunar zircon: Application of three microprobe techniques. Amer. Mineral., 81, 902- 912. 
المعادن الإشعاعية الإضافية من رواسب وادي مية العبد- شمال منطقة جتار، شمال الصحراء الشرقيةـ مصر

$$
\text { صلاح صبحى البلاقصى , محمد على الزلقى , احمد على ابو ستيت }
$$

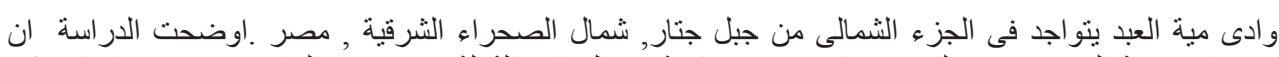

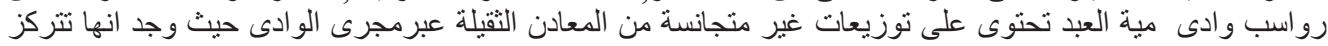

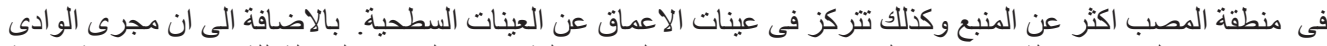

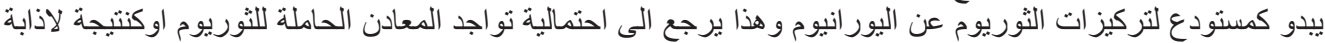

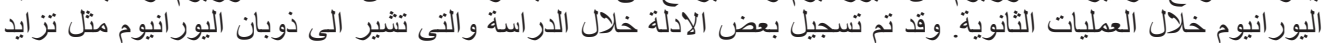

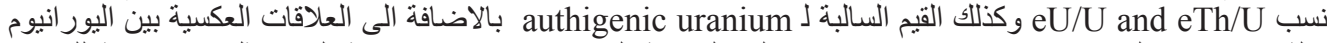

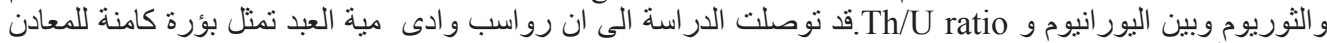

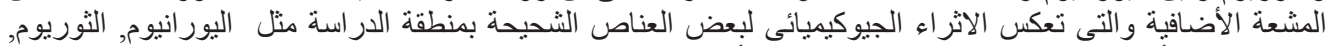

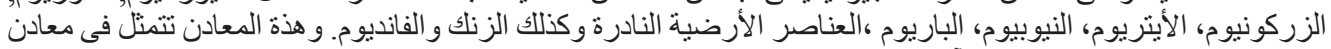

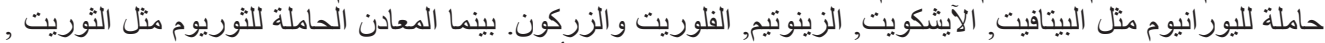

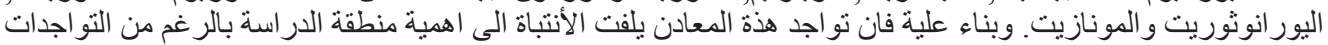

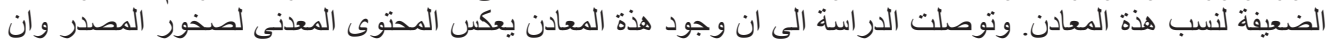

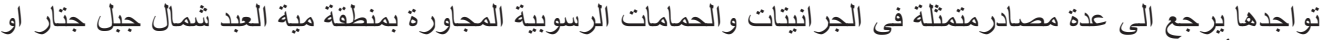

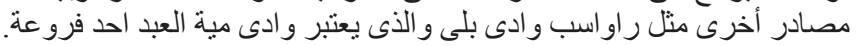

